\title{
Amino Acid Influence on Copper Binding to Peptides: Cysteine Versus Arginine
}

\author{
Zhaoxiang Wu, Francisco A. Fernandez-Lima, and David H. Russell \\ Department of Chemistry, Texas A and M University, College Station, Texas, USA
}

Matrix assisted laser desorption/ionization (MALDI) time-of-flight (TOF) mass spectrometry (MS) and theoretical calculations [density functional theory (DFT)] were utilized to investigate the influence of cysteine side chain on $\mathrm{Cu}^{+}$binding to peptides and how $\mathrm{Cu}^{+}$ions competitively interact with cysteine $\left(-\mathrm{SH} / \mathrm{SO}_{3} \mathrm{H}\right)$ versus arginine. Results from theoretical and experimental (fragmentation reactions) studies on $[\mathrm{M}+\mathrm{Cu}]^{+}$and $[\mathrm{M}+2 \mathrm{Cu}-\mathrm{H}]^{+}$ions suggest that cysteine side chains $(-\mathrm{SH})$ and cysteic acid $\left(-\mathrm{SO}_{3} \mathrm{H}\right)$ are important $\mathrm{Cu}^{+}$ligands. For example, we show that $\mathrm{Cu}^{+}$ions are competitively coordinated to the $-\mathrm{SH}$ or $\mathrm{SO}_{3} \mathrm{H}$ groups; however, we also present evidence that the proton of the $\mathrm{SH} / \mathrm{SO}_{3} \mathrm{H}$ group is mobile and can be transferred to the arginine guanidine group. For $[\mathrm{M}+2 \mathrm{Cu}-\mathrm{H}]^{+}$ions, deprotonation of the $-\mathrm{SH} / \mathrm{SO}_{3} \mathrm{H}$ group is energetically more favorable than that of the carboxyl group, and the resulting thiolate/sulfonate group plays an important role in the coordination structure of $[\mathrm{M}+2 \mathrm{Cu}-\mathrm{H}]^{+}$ions, as well as the fragmentation patterns. (J Am Soc Mass Spectrom 2010, 21, 522-533) (c) 2010 American Society for Mass Spectrometry

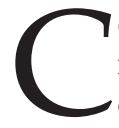
opper ions $\left(\mathrm{Cu}^{+}, \mathrm{Cu}^{2+}\right)$ play important roles in many chemical and biochemical processes, including oxidation, dioxygen transport, and electron transfer and, in many cases, the functions in these processes result from copper ions either as mono-metal or multi-metal complexes of peptides or proteins [1-5]. Redox chemistry $\left(\mathrm{Cu}^{2+} \leftrightarrow \mathrm{Cu}^{+}\right)$is involved in many enzymatic processes, but there are numerous examples, such as copper chaperone proteins and copper transport proteins, where the biological processes are limited to a single oxidation state, i.e., $\mathrm{Cu}^{2+}$ or $\mathrm{Cu}^{+}$[6]. Most of our knowledge concerning copper in biological systems is derived from solution and solid-state studies [7]; however, studies of gas-phase $\mathrm{Cu}$-peptide and $\mathrm{Cu}$ protein interactions may provide new understanding of peptide-metal ion interactions in low dielectric environments [8-11]. Although comparisons of gas-phase and solution-phase data could potentially yield important information regarding solvent dependent $\mathrm{Cu}$-biomolecule interactions, the ligand interactions in gas phase and solution phase are typically very different. For example, in solution, the side chains of basic amino acids (arginine, lysine, and histidine) are protonated, which reduces the $\mathrm{Cu}^{+}$and $\mathrm{Cu}^{2+}$ binding energies of $\mathrm{N}$-donor ligands, whereas in the gas phase, $\mathrm{Cu}^{+}$and $\mathrm{Cu}^{2+}$ have strong preferences for binding to arginine, lysine, and histidine [12, 13].

Much of the previous work on gas-phase peptide$\mathrm{Cu}^{+}$and peptide- $\mathrm{Cu}^{2+}$ complexes was directed toward the relative binding energies of $\mathrm{Cu}^{+}$and $\mathrm{Cu}^{2+}$ to

Address reprint requests to Dr. D. H. Russell, Department of Chemistry, Texas A and M University, College Station, TX 77843, USA. E-mail: russell@mail.chem.tamu.edu specific amino acids and how the relative $\mathrm{Cu}$ ion binding energies affect the fragmentation reactions of the complex [12-18]. More recently, Lim and Vachet developed a methodology based on metal-catalyzed oxidation (MCO) reactions and mass spectrometry (MS) to determine the $\mathrm{Cu}^{2+}$ binding sites in copper metalloproteins [19]. They utilize MCO reactions to oxidize the amino acids in the $\mathrm{Cu}^{2+}$ binding sites and MS to identify the amino acids that have been oxidized [20, 21]. We recently reported the synthesis of a "paddlewheel" dinuclear copper matrix that afforded new capabilities for studies of both mono-metal and multimetal containing peptide complexes [22]. These studies clearly illustrated that the C-terminal carboxyl group is an important $\mathrm{Cu}^{+}$ligand, especially for multi-copper peptide ions such as $[\mathrm{M}+2 \mathrm{Cu}-\mathrm{H}]^{+}$, whereas the C-terminal amide or the methyl ester group has less influence on the $\mathrm{Cu}^{+}$coordination. The differences in the binding sites for the mono-metal and di-metal species arise as a result of deprotonation of the acidic C-terminal carboxyl and, as a consequence, the $\mathrm{Cu}^{+}$ ions are charge-solvated by the resulting carboxylate, the lysine $€$-amino group, and the backbone amide groups [22].

In biological systems, cysteine is an important ligand in terms of the functions of copper proteins [23-26], and $35 \%$ of the copper $\left(\mathrm{Cu}^{+}, \mathrm{Cu}^{2+}\right)$ ligands are cysteine residues [27-29]. For example, copper-zinc superoxide dismutase ( $\mathrm{Cu} / \mathrm{Zn} \mathrm{SOD})$, a copper containing protein, which catalyzes the conversion of superoxide anion $\left(\mathrm{O}_{2}{ }^{-}\right)$into $\mathrm{O}_{2}$ and $\mathrm{H}_{2} \mathrm{O}_{2}$, protects cells against oxidative stress [30]. It has been suggested that cysteine (position 111) in $\mathrm{Cu} / \mathrm{Zn} \mathrm{SOD}$ is a potential copper ligand that is responsible for the function of $\mathrm{Cu} / \mathrm{Zn}$ SOD [26]. Cys111 
is also a primary target for oxidative modification, and the so-called "copper hypothesis" suggests that copper bound to or released by mutant SOD generates free radicals that cause oxidative damage to motor neurons [25]. These studies suggest that understanding how copper ions $\left(\mathrm{Cu}^{+}, \mathrm{Cu}^{2+}\right)$ interact with cysteine residues is essential to understanding the biological functions of copper proteins.

In this paper, we investigate the fragmentation chemistry of $[\mathrm{M}+\mathrm{xCu}-(\mathrm{x}-1) \mathrm{H}]^{+}(\mathrm{x}=1,2)$ ions in an effort to determine the influence of the cysteine residue on the $\mathrm{Cu}^{+}$binding, specifically competition for $\mathrm{Cu}^{+}$ between cysteine and the guanidine group of arginine. Theoretical calculations are also used to generate the candidate structures of the peptide-metal ion complex, which provide theoretical evidences to support our experimental observations. In related work, Vachet and coworkers compared the effects of ligand donor group on dissociation of $\mathrm{Cu}(\mathrm{II})$ complexes, and their results suggest that $\mathrm{Cu}^{2+}$ ions prefer to remain coordinated to thio group rather than other functional groups such as amino and imidazole [31, 32]. Kass and coworkers utilized H/D exchange experiments and high level calculations to compare the gas-phase acidities of the cysteine thiol group and carboxyl group [33]. They reported that the side-chain thiol in cysteine is more acidic than the carboxyl group in gas phase, and deprotonated cysteine is thus predicted to be a thiolate ion [33]. If this is the case, the deprotonation of the thiol group would be highly competitive with that at the carboxyl group. For peptides containing both cysteine and arginine residues, it appears likely that the thiolate group could function as an important $\mathrm{Cu}^{+}$ion ligand. This study focuses on the competitive binding of $\mathrm{Cu}^{+}$ ions to peptides that contain both cysteine and arginine.

\section{Experimental}

Copper oxide $(\mathrm{CuO})$ and $\alpha$-cyano-4-hydroxycinnamic acid (CHCA) were obtained from Sigma (St. Louis, MO, USA). CHCA was recrystallized in ethanol before use. The $\alpha$-cyano-4-hydroxycinnamic acid (CHCA) copper salt (CHCA) ${ }_{4} \mathrm{Cu}_{2}$ was synthesized as previous described [22]. The organic solvents $\left(\mathrm{CH}_{3} \mathrm{OH}, \mathrm{CH}_{3} \mathrm{CN}\right)$ used for mass spectrometry were HPLC grade, and the water was in high purity (18M $\Omega$; Barnstead International, Dubuque, IA, USA). Laminin (925-933) (CDPGYIGSR) and Cys-Kemptide (CLRRASLG) were purchased from Sigma (St. Louis, MO, USA) and used without further purification. Cysteine residues were alkylated [34] or oxidized [35] following standard protocols.

\section{Mass Spectrometry}

The MALDI experiments described herein were performed on a tandem time-of-flight mass spectrometer (4700 Proteomics Analyzer, Applied Biosystems, Framingham, MA, USA). Tandem mass experiments were performed using a collision energy setting of $1 \mathrm{kV}$ and air as the collision gas. (CHCA) ${ }_{4} \mathrm{Cu}_{2}(10 \mathrm{mg} / \mathrm{mL}$ in $60 \%$ acetonitrile containing $0.1 \%$ trifluoacetic acid) was used as the MALDI matrix to generate [peptide $+\mathrm{xCu}-$ $(x-1) \mathrm{H}]^{+}$ions [22]. Peptide samples $(0.5 \mathrm{nmol})$ were mixed with matrix solution at a ratio of 1:3 (vol:vol) and a $1 \mu \mathrm{L}$ aliquot was deposited to a stainless steel target. Samples were dried in air at room temperature.

\section{Theoretical Calculations}

Theoretical calculations using density functional theory (DFT) were performed to gain a better understanding of the stability of the peptide- $\mathrm{Cu}$ ion structures. The B3LYP LACV3P basis set (DFT/B3LYP/LACV3P**)
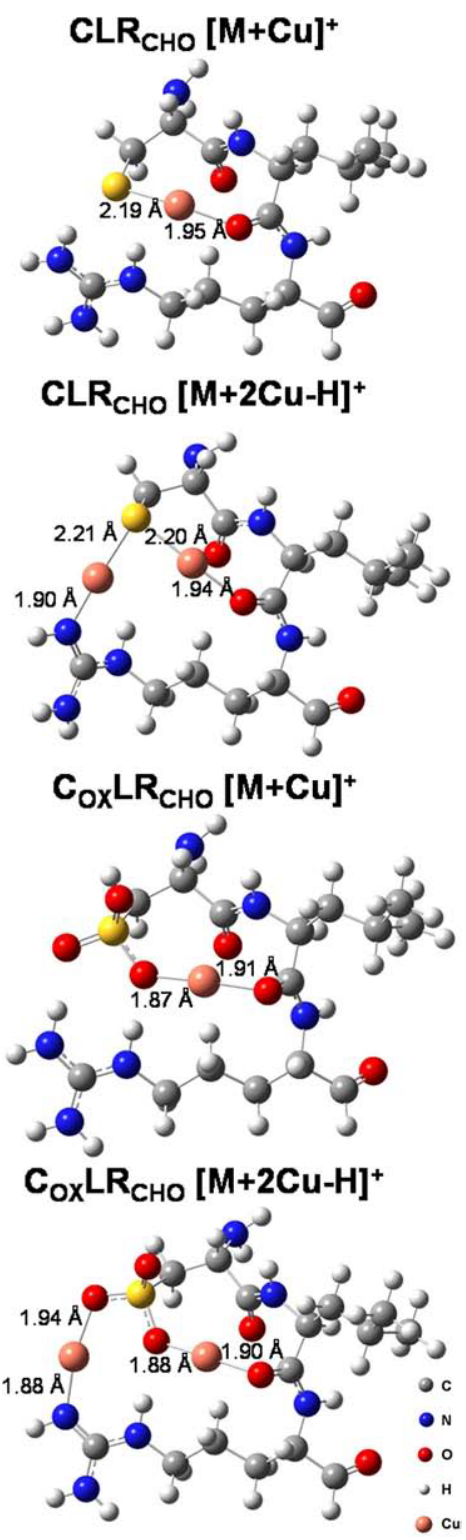

Figure 1. Lowest energy candidate structures obtained at the DFT /B3LYP/LACV3P** level for the $[\mathrm{M}+\mathrm{Cu}]^{+}$and $[\mathrm{M}+2 \mathrm{Cu}-$ $\mathrm{H}]^{+}$ions of peptides CLR $\mathrm{CHO}_{\mathrm{O}}$ and $\mathrm{C}_{\mathrm{ox}} \mathrm{LR}_{\mathrm{CHO}}$. The " ${ }_{\mathrm{CHO}}$ " denotes an aldehyde C-terminus. For comparison purposes, other candidate structures are included in the Supplemental Information. 
was used for these studies [36-38]. The LACV3P basis set is a triple- $\zeta$ contraction of the LACVP basis set [39] developed and tested at Schrödinger, Inc. [40]. In particular, $\mathrm{Cu}$ ions were treated using effective core potentials, while all the other atoms were treated with the $6-311 G^{* *}$ basis set. No symmetry restriction of any kind was imposed in the process of geometry optimization. A vibration frequency analysis was performed for all the optimized structures at the level of calculation employed. For the reported structures, all frequencies are observed to be real, indicating that they correspond to the true minima in the respective potential energy hypersurfaces. All calculations were performed with the Jaguar 6.0 software using the pseudospectral method to minimize the computational time [40].

Candidate structures were constructed to study the copper ion(s) attachment to a small, model peptide sequence CLR. Initial calculations of copper ion(s) interacting with the oxidized and non-oxidized form of the Cys side chain were performed to minimize the computational time. As a result, the backbone orientations and docking sites of the copper ion(s) for both forms of the Cys side chain were obtained. Analogous, backbone orientations and docking sites for the Arg side chain were explored. These configurations were used as starting geometries for the peptide sequence

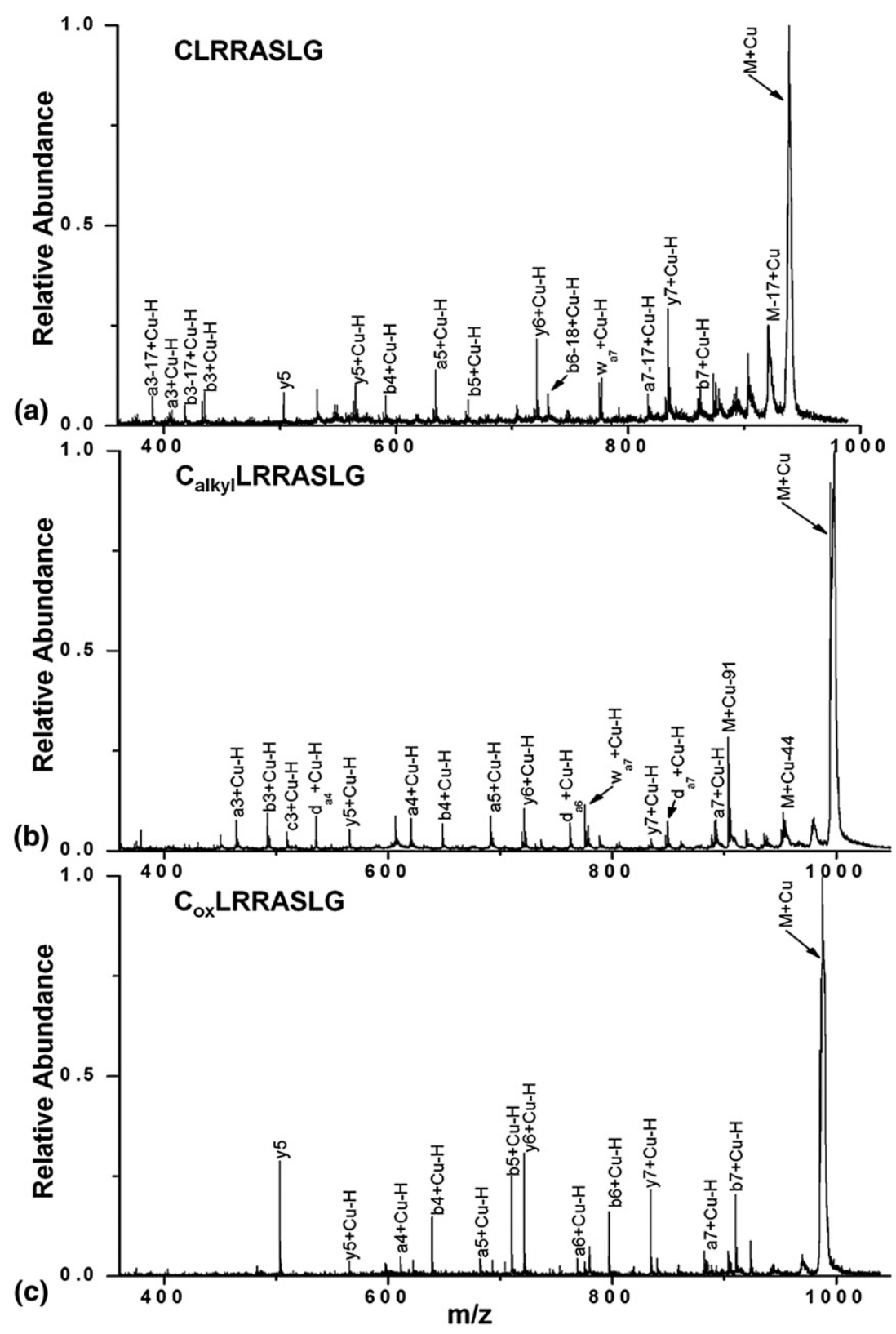

Figure 2. Fragment ion spectra of the $[\mathrm{M}+\mathrm{Cu}]^{+}$ions of (a) CLRRASLG, (b) $\mathrm{C}_{\text {alkyl }}$ LRRASLG, (c) $\mathrm{C}_{\text {ox }}$ LRRASLG. The 91 mass shift (i.e., $[\mathrm{M}+\mathrm{Cu}-91]^{+}$in $(\mathbf{b})$ is due to the loss of the alkylated cysteine side chain $\left(\mathrm{SHCH}_{2} \mathrm{CONH}_{2}\right)$. 
CLR. Copper attachments involving the C-terminus were explored in a previous paper [22] and were not considered here. Candidate structures and geometry files of the peptide sequence CLR for the oxidized and non-oxidized form of the Cys side chain are included in the Supplemental Information, which can be found in the electronic version of this article.

\section{Results and Discussion}

Previous work has shown that $\mathrm{Cu}^{+}$ions preferentially bind to electron-rich systems in gas phase (i.e., Nterminal amino group, the side chain of lysine, histidine, and arginine, and the deprotonated C-terminal carboxyl group) $[17,22]$. Kass and coworkers reported that in gas phase, the cysteine side-chain thiol is more acidic than the carboxyl group, and deprotonated cysteine is thus predicted to be a thiolate ion, making it a potential electron rich group [33]. Therefore, it would be interesting to see how the $\mathrm{Cu}^{+}$ions competitively bind to the cysteine thiol versus other electron-rich system such as the guanidino group of arginine. The potential for interactions of cysteine thiol with $\mathrm{Cu}^{+}$ions were first examined by using theoretical calculations (at the DFT/B3LYP/LACV3P** level) on a small, model peptide sequenced CLR. The C-terminus was blocked by addition of an aldehyde group to eliminate the possible interaction of a carboxyl group with $\mathrm{Cu}^{+}$ions, which was described previously [22]. For a comparison, the interactions of $\mathrm{Cu}^{+}$ions with cysteine thiol versus cysteine sulfonic acid were also examined. Figure 1 contains the lowest energy structures obtained at the DFT/B3LYP/LACV3P** level for the $[\mathrm{M}+\mathrm{Cu}]^{+}$and $[\mathrm{M}+2 \mathrm{Cu}-\mathrm{H}]^{+}$ions of $\mathrm{CLR}_{\mathrm{CHO}}$ and $\mathrm{C}_{\mathrm{ox}} \mathrm{LR}_{\mathrm{CHO}}$ (" ${ }_{\mathrm{CHO}}$ " denotes an aldehyde C-terminus). These simulated structures reveal that the guanidino group of arginine is an important ligand for $\mathrm{Cu}^{+}$ions; however, the cysteine side-chain also participates in the coordination of $\mathrm{Cu}^{+}$

(a)

CLRRASLG
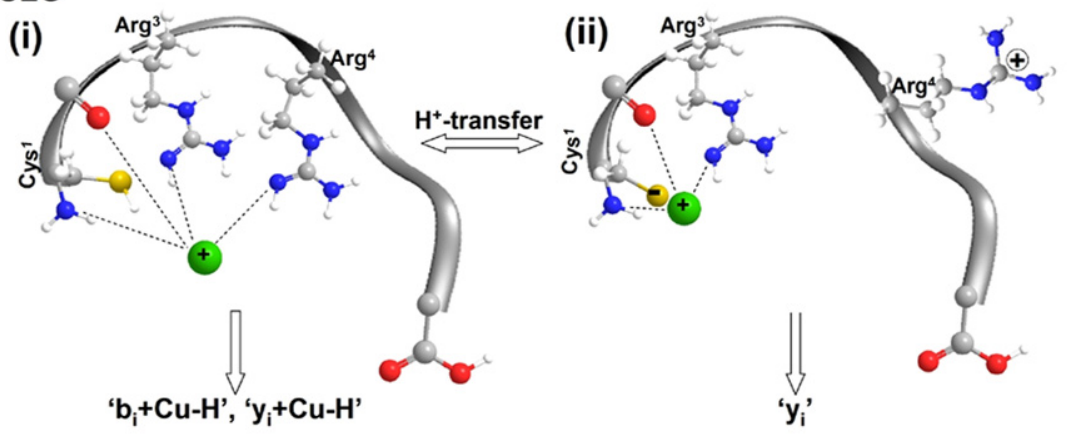

$C_{\text {alkyl }}$ LRRASLG

(b)
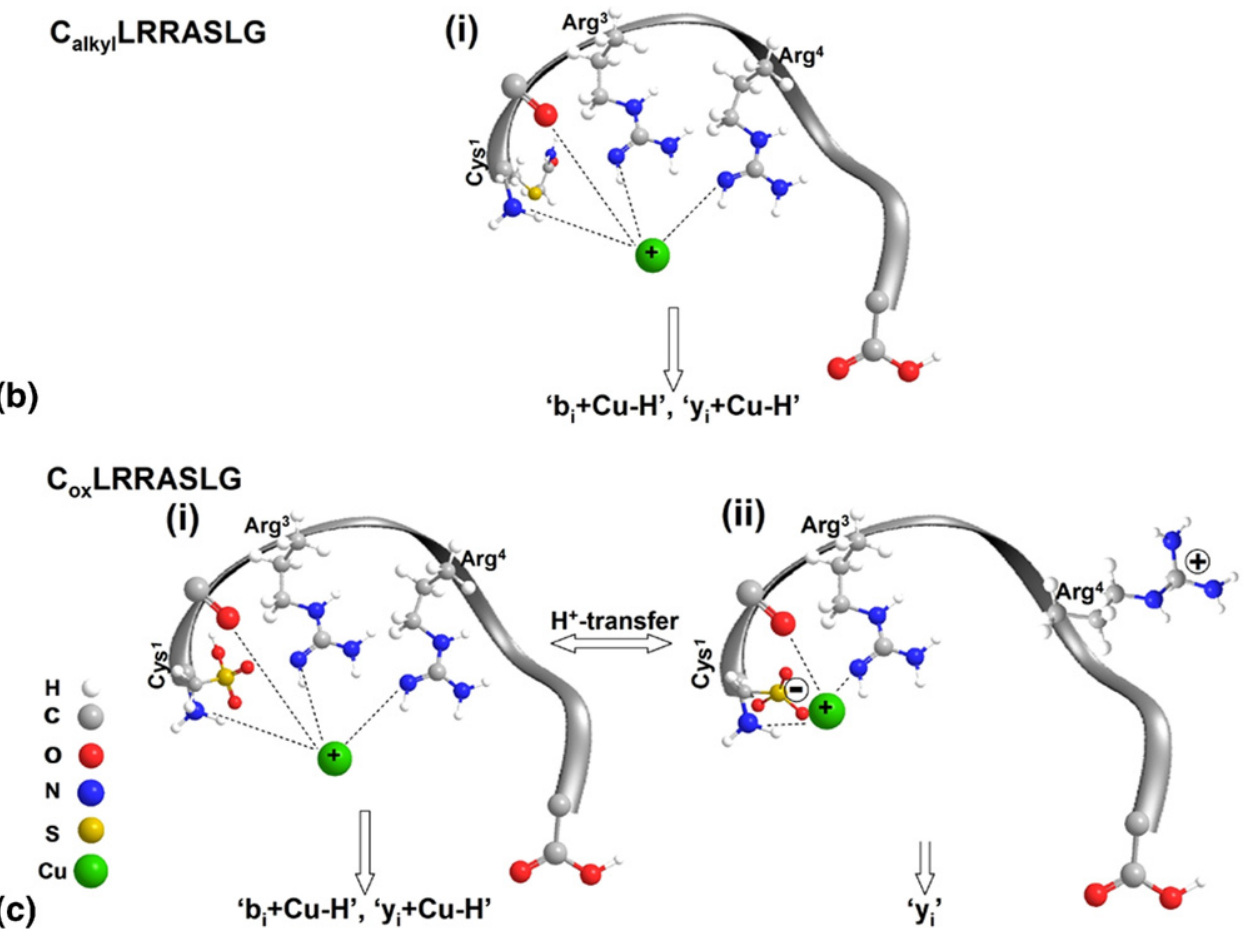

Scheme 1 
ions. For example, a plausible configuration for $[\mathrm{M}+$ $\mathrm{Cu}]^{+}$ions is that the proton from the initial thiol or the sulfonic acid group is transferred to the basic guanidine, resulting in a protonated arginine side chain, and the $\mathrm{Cu}^{+}$ion is charge-solvated by the resulting thiolate or sulfonate group and the backbone carbonyls (see Figure 1). In addition, deprotonation of the thiol or sulfonic acid is energetically favorable for $[\mathrm{M}+2 \mathrm{Cu}-$ $\mathrm{H}]^{+}$ions and, as a consequence, the interaction of the resulting thiolate or sulfonate group with $\mathrm{Cu}^{+}$ions contributes to the gas-phase structure of the $[\mathrm{M}+2 \mathrm{Cu}-$ $\mathrm{H}]^{+}$ions. These results raise several questions regarding the binding of $\mathrm{Cu}^{+}$ions to thiol/sulfonic acid versus guanidine in larger peptide ions. How does the competitive $\mathrm{Cu}^{+}$binding affect the fragmentation of the peptides?

To address these questions, we examined the fragmentation reactions of the $[\mathrm{M}+\mathrm{Cu}]^{+}$and $[\mathrm{M}+2 \mathrm{Cu}-$ $\mathrm{H}]^{+}$ions of cys-kemptide (CLRRASLG). We also examined the modified Cys-kemptide where the $\mathrm{N}$-terminal cysteine was modified by iodoacetamide [34] or performic acid [35], denoted as $\mathrm{C}_{\text {alkyl }}$ or $\mathrm{C}_{\mathrm{ox}}$, respectively. Figure 2 contains the fragment ion spectra of the $[\mathrm{M}+$ $\mathrm{Cu}]^{+}$ions for peptides XLRRASLG $\left(X=C, C_{a l k y l}\right.$ and $\left.\mathrm{C}_{\mathrm{ox}}\right)$. In the case of CLRRASLG, the fragment ion spectrum of $[\mathrm{M}+\mathrm{Cu}]^{+}$ions contains both $\mathrm{C}$ - and

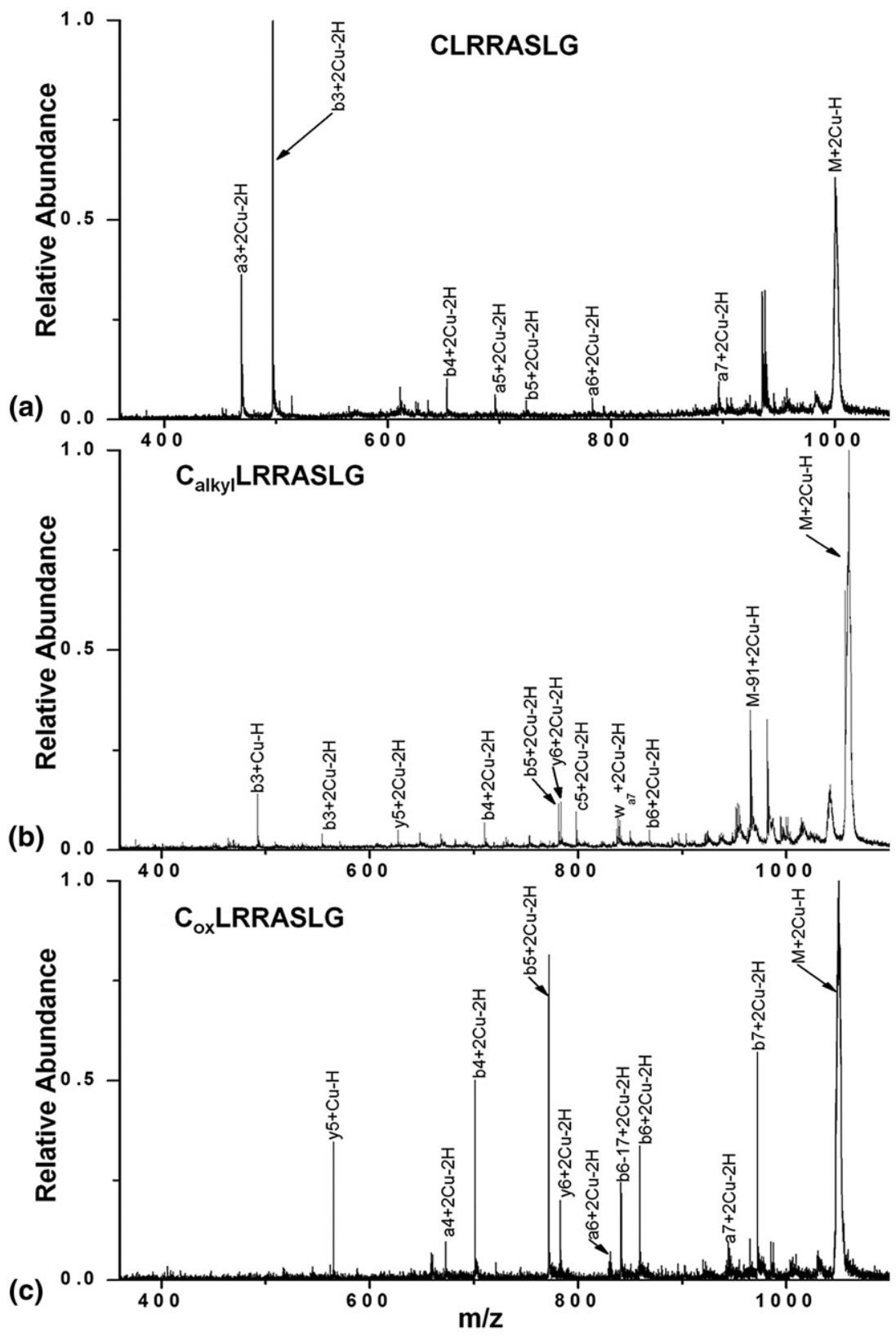

Figure 3. Fragment ion spectra of the $[\mathrm{M}+2 \mathrm{Cu}-\mathrm{H}]^{+}$ions of (a) CLRRASLG, (b) $\mathrm{C}_{\text {alkyl }}$ LRRASLG, (c) $\mathrm{C}_{\mathrm{ox}}$ LRRASLG. The 91 mass shift, i.e., $[\mathrm{M}-91+2 \mathrm{Cu}-\mathrm{H}]^{+}$in (b) is due to the loss of the alkylated cysteine side chain $\mathrm{SHCH}_{2} \mathrm{CONH}_{2}$. 
N-terminal fragment ions, including $\left[\mathrm{a}_{\mathrm{i}}+\mathrm{Cu}-\mathrm{H}\right]^{+},\left[\mathrm{b}_{\mathrm{i}}+\right.$ $\mathrm{Cu}-\mathrm{H}]^{+}$, and $\left[\mathrm{y}_{\mathrm{i}}+\mathrm{Cu}-\mathrm{H}\right]^{+}$ions. The relative abundance ratios of $\mathrm{C}$ - and $\mathrm{N}$-terminal fragment ions are $52 \%$ and $48 \%$, respectively. We interpret this observation as evidence that $\mathrm{Cu}^{+}$can bind to either $\mathrm{Arg}^{3}$ or $\mathrm{Arg}^{4}$, and there is no strong preference for binding of $\mathrm{Cu}^{+}$to the N-terminal cysteine. Scheme 1Ai contains a proposed configuration showing that $\mathrm{Cu}^{+}$interacts with the guanidine group(s) of arginine(s), the backbone carbonyls, and the N-terminal amine group. Note, however, that a small peak corresponding to the $\mathrm{y}_{5}$ ion without $\mathrm{Cu}^{+}$is observed. An explanation for the formation of the $y_{i}$ ions, which is consistent with the theoretical results for CLR, is that $\mathrm{Cu}^{+}$promotes intramolecular proton transfer from the cysteine thiol to the arginine guanidine. That is, the $\mathrm{Cu}^{+}$ion is chargesolvated by the resulting thiolate, and the arginine side chain is protonated (Scheme 1Aii. Note that the protonated guanidine group is projected away from the $\mathrm{Cu}^{+}$ charge solvating center because this group is not a good $\mathrm{Cu}^{+}$ligand, i.e., the group acts as an isolated charge site). This explanation is further supported by the absence of $y_{i}$ fragment ions for the peptide $\mathrm{C}_{\text {alkyl }}$ LRRASLG (Figure $2 b$ ). That is, the $-\mathrm{CH}_{2} \mathrm{CONH}_{2}$ group blocks the pathway for the intramolecular proton transfer thus all fragment ions are formed with $\mathrm{Cu}^{+}$attached (Scheme 1Bi). Interestingly, when the cysteine thiol is oxidized to sulfonic acid, the abundance of the $y_{5}$ is increased (Figure 2c). Thus, apparently, oxidation of the cysteine increases the extent of the intramolecular proton transfer, generating larger population of the conformation shown in Scheme 1Cii than that shown in Scheme 1Aii.

We also examined the fragmentation chemistry of the $[\mathrm{M}+2 \mathrm{Cu}-\mathrm{H}]^{+}$ions for XLRRASLG $\left(\mathrm{X}=\mathrm{C}, \mathrm{C}_{\text {alkyl }}\right.$ and $\mathrm{C}_{\mathrm{ox}}$ ). Fragment ion spectra of the $[\mathrm{M}+2 \mathrm{Cu}-\mathrm{H}]^{+}$ ions are very different from that of the $[\mathrm{M}+\mathrm{Cu}]^{+}$ions, and the cysteine modifications significantly affect the fragmentation results. For example, we observe predom- (a)

CLRRASLG

(b)
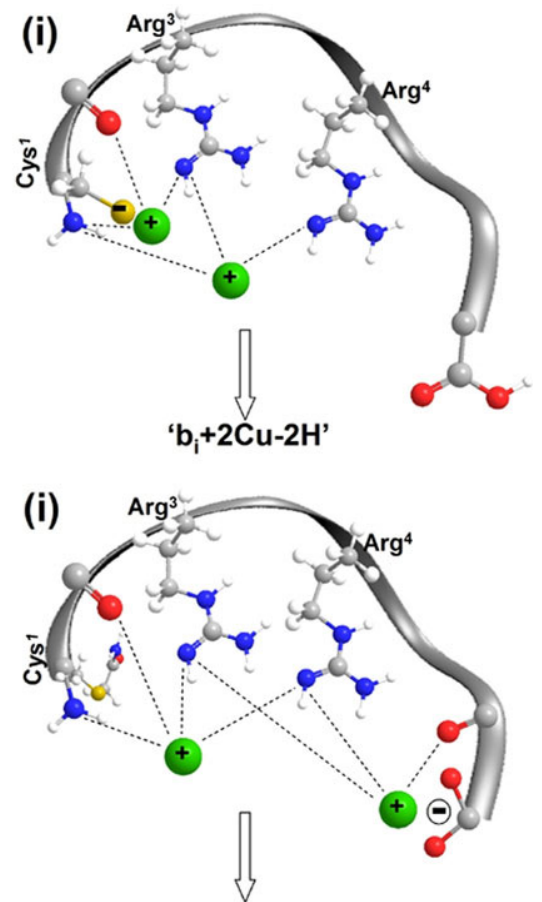

'b $b_{i}+2 C u-2 H ', y_{i}+2 C u-2 H '$

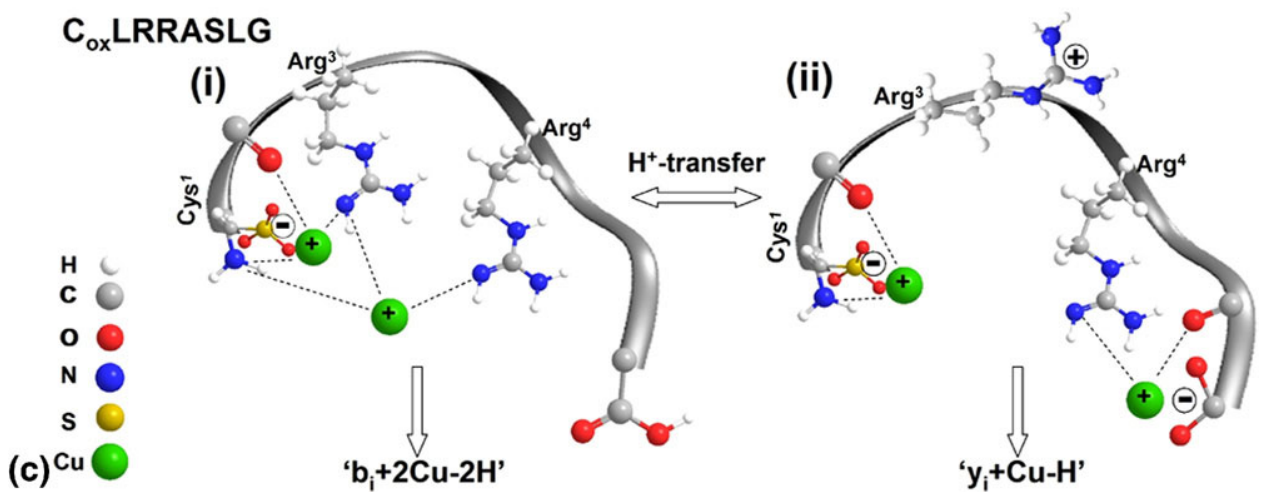

Scheme 2 
inantly $\left[\mathrm{a}_{3}+2 \mathrm{Cu}-2 \mathrm{H}\right]^{+}$and $\left[\mathrm{b}_{3}+2 \mathrm{Cu}-2 \mathrm{H}\right]^{+}$fragment ions for the $[\mathrm{M}+2 \mathrm{Cu}-\mathrm{H}]^{+}$ions of CLRRASLG (Figure 3a); however, very different fragment ions are observed if the cysteine is alkylated (Figure 3b). A plausible explanation for the high abundance of the N-terminal fragment ions is that the deprotonation of the cysteine side chain occurs rather than the C-terminal carboxyl group, owing to its higher gas-phase acidity over that of the carboxyl [33]. Consequence, the two $\mathrm{Cu}^{+}$ions are strongly coordinated to $\mathrm{N}$-terminal CLR residues. That is, the two $\mathrm{Cu}^{+}$ions are charge-solvated by the resulting thiolate, the arginine guanidine(s), the backbone carbonyl(s), and the N-terminal amine (Scheme 2Ai). This interpretation is further evidenced by the fragmentation reactions of the peptide $C_{\text {alkyl }}$ LRRASLG (Figure $3 b$ ). That is, no significant preference of the N-terminal fragment ions for $[\mathrm{M}+2 \mathrm{Cu}-\mathrm{H}]^{+}$are observed, considering that the abundance ratio of $\mathrm{N}$-/C-fragment ions is $\sim 58$ / 42 for $C_{\text {alkyl }}$ LRRASLG (Figure $3 b$ ) versus $\sim 100 / 0$ for CLRRASLG (Figure 3a). These results are in good agreement with our theoretical calculations, where deprotonation of the cysteine thiol is energetically favorable for [M + $2 \mathrm{Cu}-\mathrm{H}]^{+}$ions, and blocking the thiol results in a different deprotonation site along the peptide backbone, which significantly changes the $\mathrm{Cu}^{+}$coordination environment for $[\mathrm{M}+2 \mathrm{Cu}-\mathrm{H}]^{+}$ions (Scheme 2Bi).

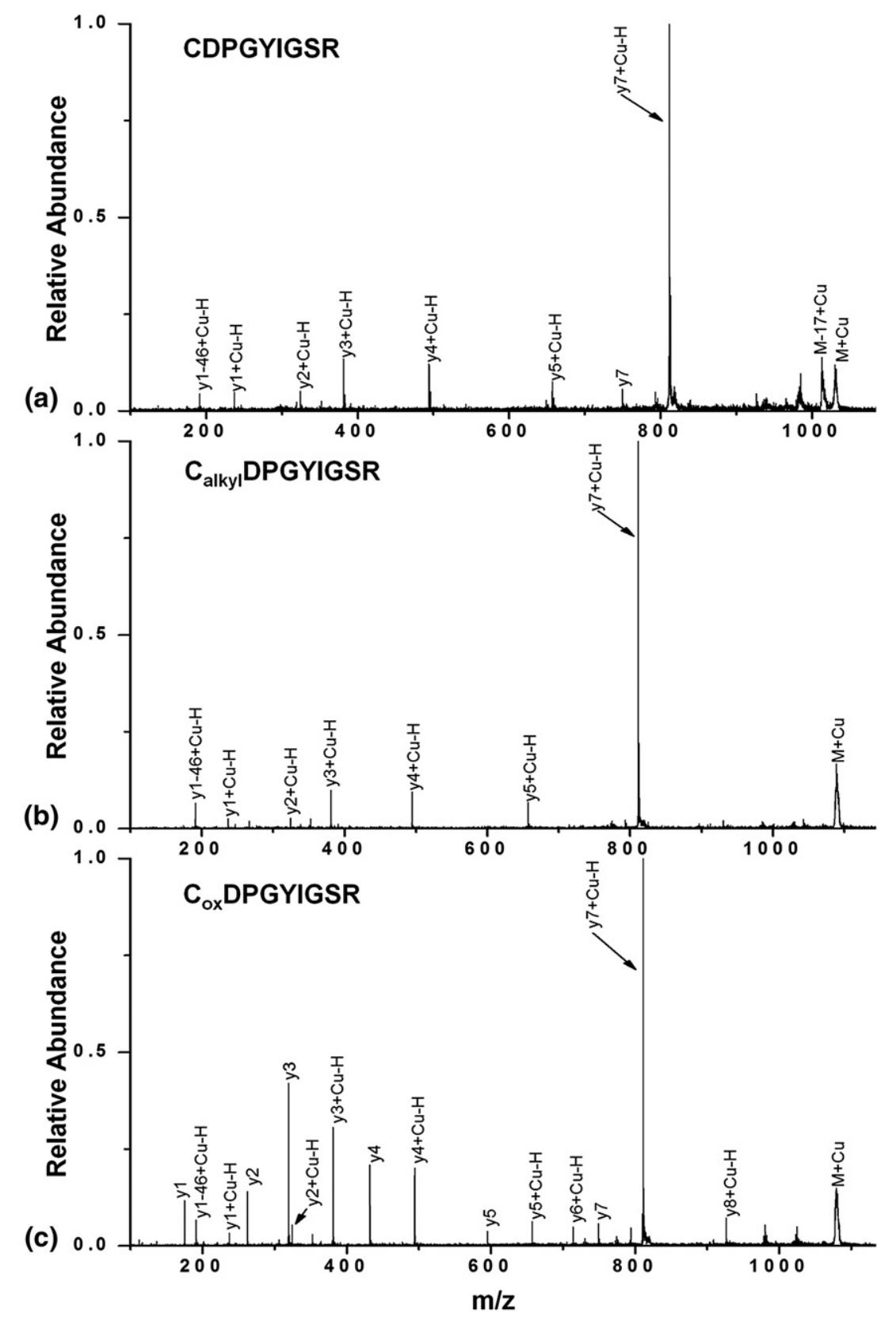

Figure 4. Fragment ion spectra of the $[\mathrm{M}+\mathrm{Cu}]^{+}$ions of (a) CDPGYIGSR, (b) $\mathrm{C}_{\text {alkyl }}$ DPGYIGSR, (c) C ox DPGYIGSR. 
Oxidizing the cysteine also influences the $\mathrm{Cu}^{+}$coordination. For example, the fragment ion spectrum of the $\mathrm{C}_{\text {ox }}$ LRRASLG $[\mathrm{M}+2 \mathrm{Cu}-\mathrm{H}]^{+}$ion contains predominantly $\left[b_{\mathrm{i}}+2 \mathrm{Cu}-2 \mathrm{H}\right]^{+}(\mathrm{i} \geq 4)$ fragment ions; note that the $\left[b_{3}+2 \mathrm{Cu}-2 \mathrm{H}\right]^{+}$fragment ions are absent. Thus, apparently the position of arginine also plays a role in the $\mathrm{Cu}^{+}$coordination, i.e., $\mathrm{Cu}^{+}$ions prefer to bind to $\mathrm{Arg}^{4}$ rather than $\mathrm{Arg}^{3}$ for $\mathrm{C}_{\mathrm{ox}}$ LRRASLG. Two additional observations are consistent with our proposed $\mathrm{Cu}^{+}$ binding preference of $\mathrm{Arg}^{4}$ : (1) the smallest N-terminal fragment ions of $[\mathrm{M}+2 \mathrm{Cu}-\mathrm{H}]^{+}$ions for $\mathrm{C}_{\mathrm{ox}}$ LRRASLG are $\left[\mathrm{b}_{4}+2 \mathrm{Cu}-2 \mathrm{H}\right]^{+}$and $\left[\mathrm{a}_{4}+2 \mathrm{Cu}-2 \mathrm{H}\right]^{+}$(Figure $3 \mathrm{c}$ ), indicating that at least one $\mathrm{Cu}^{+}$ion is attached to either $\mathrm{Arg}^{3}$ or $\mathrm{Arg}^{4}$; and (2) the peak at $\mathrm{m} / \mathrm{z}$ 565.1, which is assigned as $\left[\mathrm{y}_{5}+\mathrm{Cu}-\mathrm{H}\right]^{+}$, suggests that $\mathrm{Arg}^{4}$ is the preferred $\mathrm{Cu}^{+}$binding site; otherwise we would expect $\left[\mathrm{y}_{6}+\mathrm{Cu}-\mathrm{H}\right]^{+}$to also be observed (Scheme 2Cii).

For comparison, we also examined the peptide Laminin (CDPGYIGSR) aimed at addressing how the $\mathrm{Cu}^{+}$ ion interacts with cysteine versus arginine if the two side chains are located at the two termini. For example, is the intramolecular proton transfer process noted above the result of close proximity of the two groups?
The $[\mathrm{M}+\mathrm{Cu}]^{+}$ion of CDPGYIGSR yields exclusively $\mathrm{C}$-terminal fragment ions (Figure $4 \mathrm{a}$ ). The $\mathrm{Cy}_{7}+\mathrm{Cu}-$ $\mathrm{H}^{+}$ion is the most abundant, which indicates an enhanced backbone cleavage between the aspartic acid and proline residue with the $\mathrm{Cu}^{+}$remaining on the $\mathrm{C}$-terminus. We interpret the preference for $\left[\mathrm{y}_{\mathrm{i}}+\mathrm{Cu}-\right.$ $\mathrm{H}]^{+}$ions, especially $\left[\mathrm{y}_{1}+\mathrm{Cu}-\mathrm{H}\right]^{+}$, as evidence that $\mathrm{Cu}^{+}$ion is bound to the arginine side-chain (Scheme 3Ai). Interestingly, we also observed a small peak corresponding to the $\mathrm{y}_{7}$ ion that does not contain $\mathrm{Cu}^{+}$; however, the $\mathrm{y}_{7}$ peak is absent for $[\mathrm{M}+\mathrm{Cu}]^{+}$ions of $\mathrm{C}_{\text {alkyl }}$ DPGYIGSR (Figure $4 \mathrm{~b}$ ), a result which suggests that the formation of $\mathrm{y}_{7}$ ion for $[\mathrm{M}+\mathrm{Cu}]^{+}$ions of CDPGYIGSR is also owing to an intramolecular proton transfer. That is, the proton from the thiol is transferred to the arginine guanidine, and $\mathrm{Cu}^{+}$is charge-solvated by the resulting thiolate group (Scheme 3Aii). More interestingly, however, when the cysteine thiol group is oxidized to sulfonic acid, the intramolecular proton transfer appears to occur to a larger extent. For example, in Figure 4c, we observe a significantly high abundance of $\mathrm{y}_{\mathrm{i}}$ ions that do not contain $\mathrm{Cu}^{+}$. The abundance ratio of the $\left[y_{i}+\mathrm{Cu}-\mathrm{H}\right]^{+}$to $\mathrm{y}_{\mathrm{i}}$ is $\sim 70 \%$ to $30 \%$. We

(a)
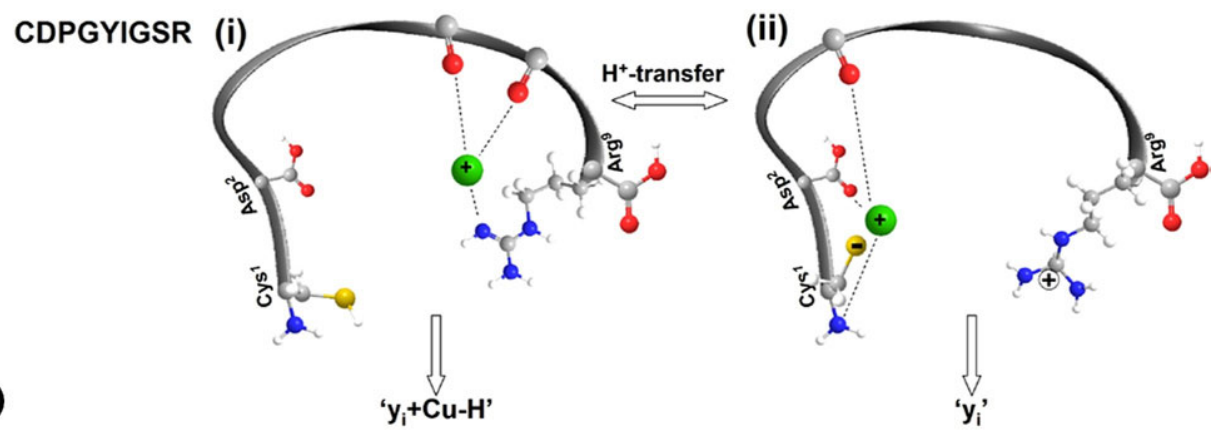

$$
\text { C alkyl DPGYIGSR }
$$

(b)
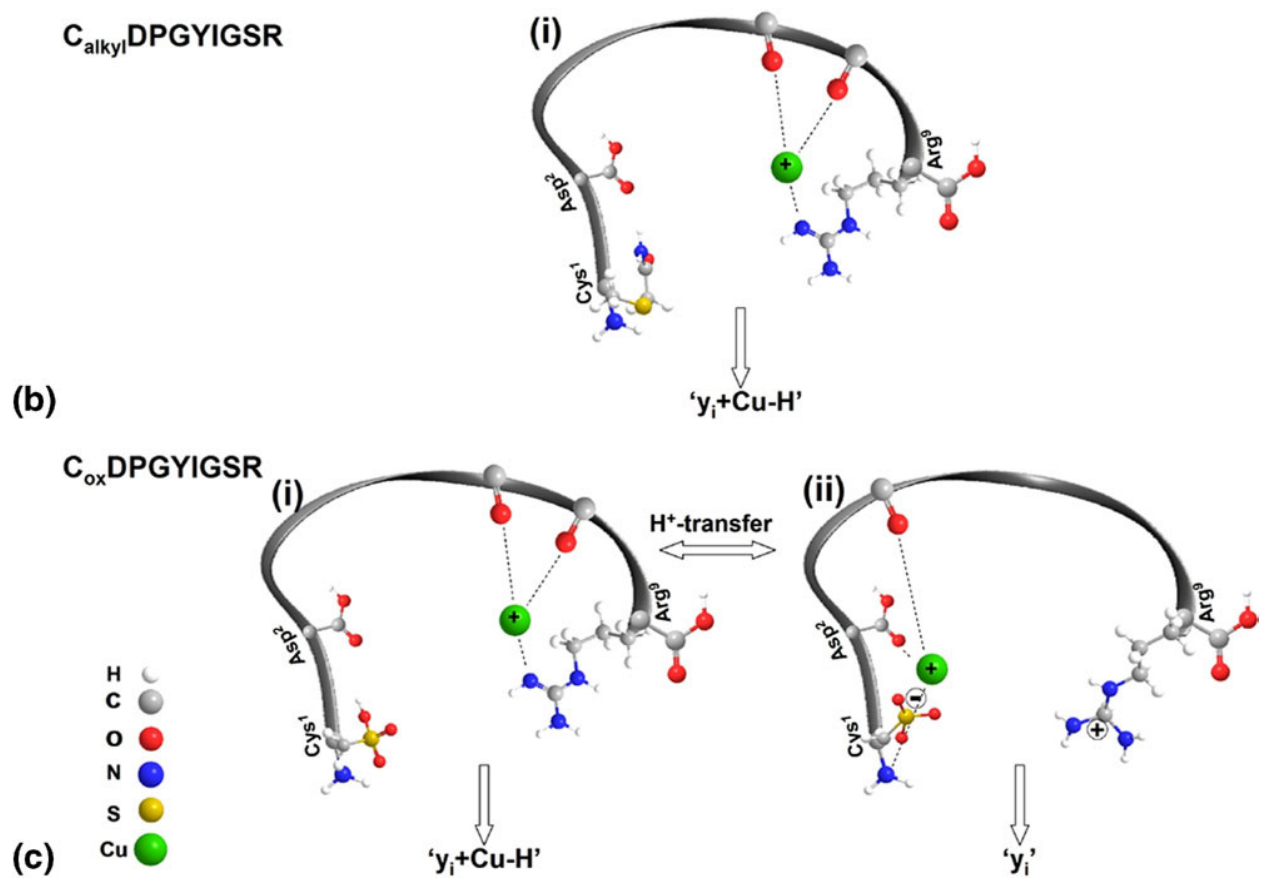

Scheme 3 
interpret this result as evidence that the coordination structure of the $[\mathrm{M}+\mathrm{Cu}]^{+}$ions is dependent on the position of the cysteine and arginine, and oxidizing the cysteine residue favors coordinate $\mathrm{Cu}^{+}$ions (Scheme 3Cii).

We also investigated the fragmentation chemistry of the $[\mathrm{M}+2 \mathrm{Cu}-\mathrm{H}]^{+}$ions of CDPGYIGSR (Figure 5). Results from these experiments suggest that the fragmentation of $[\mathrm{M}+2 \mathrm{Cu}-\mathrm{H}]^{+}$ions is sensitive to the nature of the cysteine side chain, and different fragment ion spectra are observed when the cysteine side chain is modified $\left(\mathrm{C}_{\mathrm{alkyl}}\right.$ and $\left.\mathrm{C}_{\mathrm{ox}}\right)$. For example, the fragment ion spectrum of $[\mathrm{M}+2 \mathrm{Cu}-\mathrm{H}]^{+}$ions of CDPGYIGSR contains three types of fragment ions, viz. $\left[\mathrm{y}_{\mathrm{i}}+2 \mathrm{Cu}-\right.$ $2 \mathrm{H}]^{+},\left[\mathrm{y}_{\mathrm{i}}+\mathrm{Cu}-\mathrm{H}\right]^{+}$, and $\mathrm{y}_{\mathrm{i}}$, and the relative abundance ratios of these ions are $42 \%, 48 \%$, and $10 \%$, respectively (Table 1 ). We propose that $\left[\mathrm{y}_{\mathrm{i}}+2 \mathrm{Cu}-\right.$ $2 \mathrm{H}]^{+}$and $\left[\mathrm{y}_{\mathrm{i}}+\mathrm{Cu}-\mathrm{H}\right]^{+}$are formed from the coordination conformations such as $4 \mathbf{A i}$ and $4 \mathbf{A i i}$ shown in Scheme 4, respectively; note that the differences in these two conformations depend on where the deprotonation site is, i.e., cysteine thiol or C-terminal carboxyl. We would expect that the conformation (Scheme 4Aiii) to yield predominantly $\mathrm{y}_{\mathrm{i}}$ ions with no $\mathrm{Cu}^{+}$attached. That is, the two $\mathrm{Cu}^{+}$ions are charge-solvated by the cysteine thiolate and the carboxylate of the aspartic acid, respec-

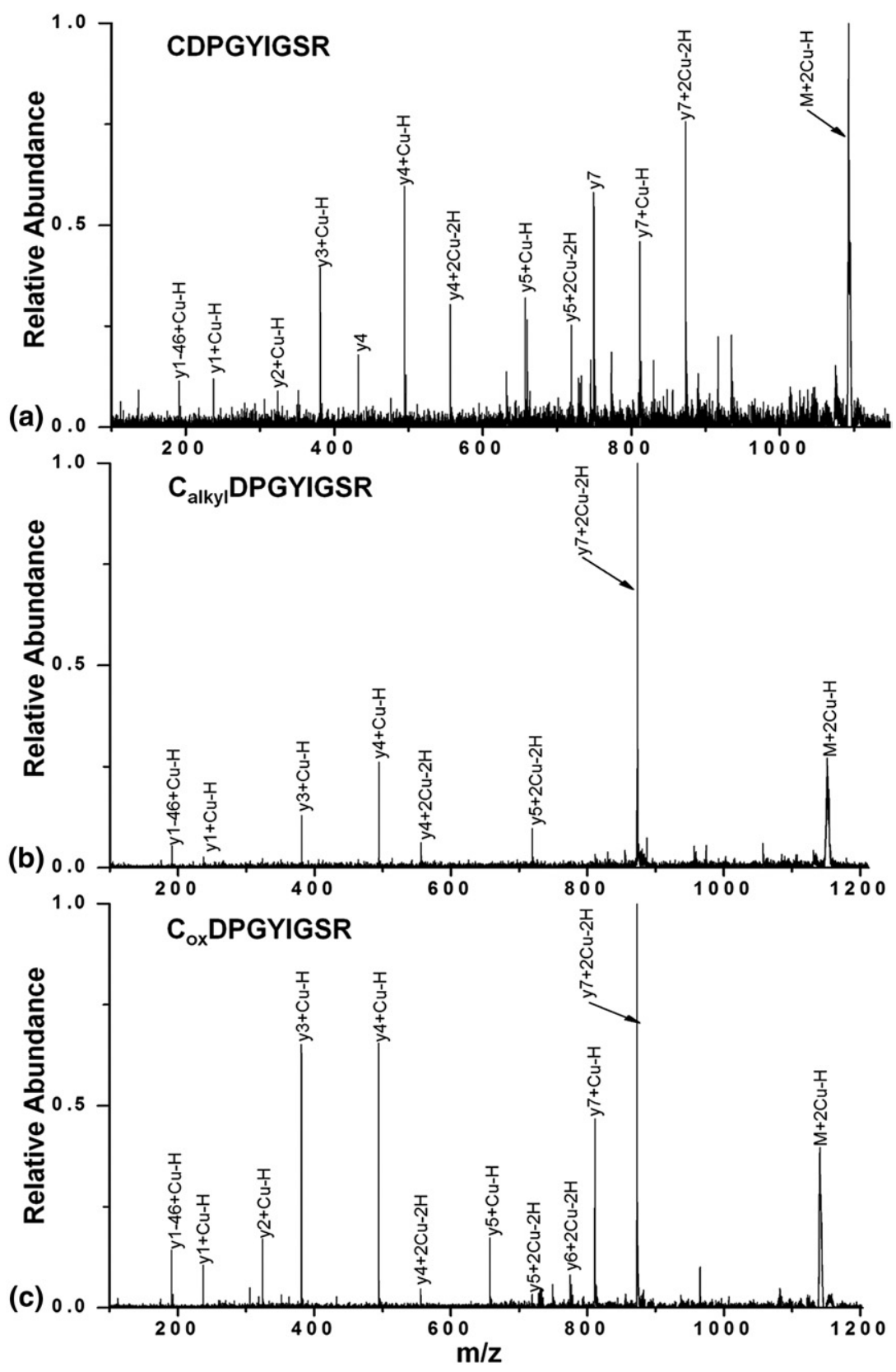

Figure 5. Fragment ion spectra of the $[\mathrm{M}+2 \mathrm{Cu}-\mathrm{H}]^{+}$ions of (a) CDPGYIGSR, (b) $\mathrm{C}_{\text {alkyl }}$ DPGYIGSR, (c) Cox DPGYIGSR. 
Table 1. Relative abundance ratio of the fragment ions for $[\mathrm{M}+\mathrm{Cu}]^{+}$and $[\mathrm{M}+2 \mathrm{Cu}-\mathrm{H}]^{+}$

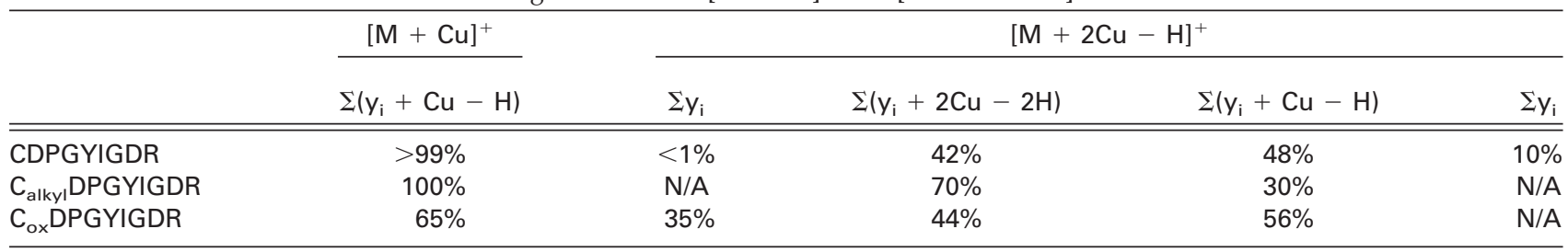

For example, for $[\mathrm{M}+\mathrm{Cu}]^{+}$ions, the relative abundance ratio of " $\mathrm{y}_{\mathrm{i}}+\mathrm{Cu}-\mathrm{H}^{\prime \prime}$ ions $=\Sigma\left(\mathrm{y}_{\mathrm{i}}+\mathrm{Cu}-\mathrm{H}\right) /\left(\Sigma\left(\mathrm{y}_{\mathrm{i}}+\mathrm{Cu}-\mathrm{H}\right)+\Sigma \mathrm{y}_{\mathrm{i}}\right)$.

tively, and the arginine side chain is protonated via an intramolecular proton transfer. This assumption is supported by the fragment ion spectrum of $\mathrm{C}_{\text {alkyl }}$ DPGYIGSR. The fragment ion spectrum of the modified peptide $\mathrm{C}_{\text {alkyl }}$ DPGYIGSR contains only two types of fragment ions, viz. $\left[\mathrm{y}_{\mathrm{i}}+2 \mathrm{Cu}-2 \mathrm{H}\right]^{+}$and $\left[\mathrm{y}_{\mathrm{i}}+\mathrm{Cu}-\mathrm{H}\right]^{+}$, and $\mathrm{y}_{\mathrm{i}}$ ions are not observed. The absence of $y_{i}$ ions for $\mathrm{C}_{\text {alkyl }}$ DPGYIGSR provides evidence that blocking the cysteine thiol group reduces the interaction with $\mathrm{Cu}^{+}$ ion. In addition, these data suggest that at least one $\mathrm{Cu}^{+}$ must be located at the C-terminus (charge-solvated by the C-terminal carboxyl and/or the arginine guanidine). For the $[\mathrm{M}+2 \mathrm{Cu}-\mathrm{H}]^{+}$ion of $\mathrm{C}_{\mathrm{ox}}$ DPGYIGSR, we observed exclusively $\left[\mathrm{y}_{\mathrm{i}}+2 \mathrm{Cu}-2 \mathrm{H}\right]^{+}$and $\left[\mathrm{y}_{\mathrm{i}}+\mathrm{Cu}-\right.$ $\mathrm{H}]^{+}$fragment ions with relative abundance ratios of $44 \%$ and $56 \%$, respectively (Table 1 ). The higher abundance of the $\left[\mathrm{y}_{\mathrm{i}}+\mathrm{Cu}-\mathrm{H}\right]^{+}$ions suggests a larger population of the conformation (Scheme 4Cii), where the sulfonic acid is the primary protonation site, and each $\mathrm{Cu}^{+}$ion is individually charge-solvated by the sulfonate and the arginine guanidine group, respectively. As a consequence, only one $\mathrm{Cu}^{+}$ion remains on the C-terminal fragment ions (Scheme 4Cii). A possible explanation for the formation of higher abundance of $\left[\mathrm{y}_{\mathrm{i}}+\mathrm{Cu}-\mathrm{H}\right]^{+}$ions is the fact that the deprotonation energy for sulfonic acid is less than that for carboxylic acid [41]. Thus, deprotonation of the sulfonic acid is more energetically favorable over that of the C-terminal carboxyl group, and the lower deprotonation energy of sulfonic acid results in a more stable coordination structure (Scheme 4Cii).

\section{Conclusions}

These studies clearly show that cysteine and cysteic acid side chains $\left(-\mathrm{SH} / \mathrm{SO}_{3} \mathrm{H}\right)$ are important $\mathrm{Cu}^{+}$ion ligands, and these metal ion-ligand interactions have a strong influence on the fragmentation chemistry of

(a)

CDPGYIGSR

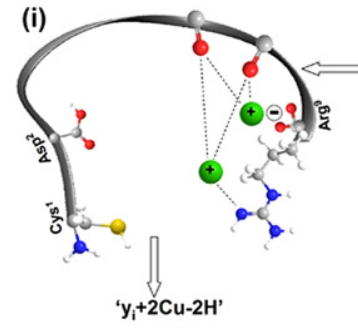

(ii)

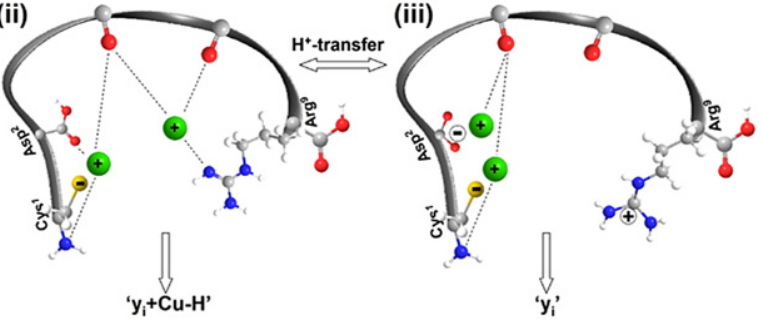

$C_{\text {alky } D P G Y I G S R}$

(b)
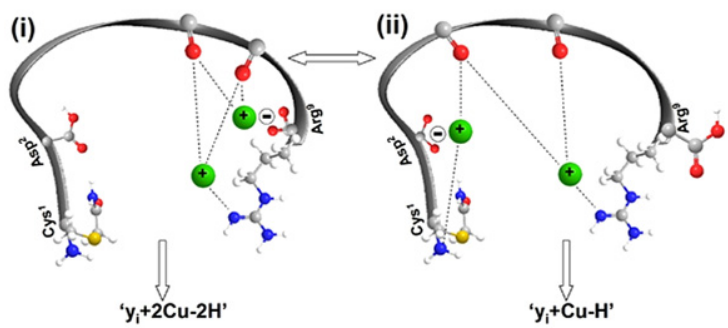

Cox DPGYIGSR

(c)
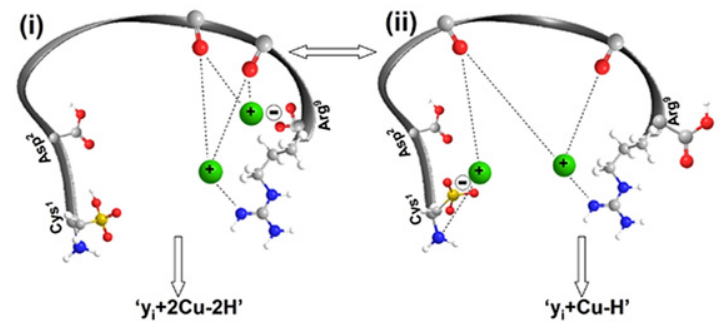

Scheme 4 
$[\mathrm{M}+\mathrm{Cu}]^{+}$and $[\mathrm{M}+2 \mathrm{Cu}-\mathrm{H}]^{+}$ions. In addition, we demonstrate that $\mathrm{Cu}^{+}$ions are competitively coordinated to the $-\mathrm{SH} / \mathrm{SO}_{3} \mathrm{H}$ groups versus guanidine group via an intramolecular proton transfer. This is probably not surprising, considering the $\mathrm{Cu}^{+}$binding energy for the two groups differs by $\sim 5 \mathrm{kcal} / \mathrm{mol}[17$, 42]. It is particularly interesting to note that upon binding of $\mathrm{Cu}^{+}$ions to the cysteine or cysteic acid side chains, the proton (on $\mathrm{SH}_{\text {or }} \mathrm{SO}_{3} \mathrm{H}$ ) is transferred to the arginine guanidine group, resulting in a thiolate- $\mathrm{Cu}^{+}$or sulfonate- $\mathrm{Cu}^{+}$group and a protonated arginine side chain. On the basis of the data reported herein, we cannot determine whether this proton migration occurs as a result of $\mathrm{Cu}^{+}$attachment to $\mathrm{SH}$ or $\mathrm{SO}_{3} \mathrm{H}$ (i.e., a process similar to that was proposed previously [13]), or whether the proton is mobilized as a result of the collisional activation process. We are currently investigating these issues further by comparing ion abundances observed by using $193 \mathrm{~nm}$ photodissociation with those observed by CID and by ion mobility-mass spectrometry (IM-MS) and molecular dynamics simulations. These studies underscore the role of peptidemetal ion interactions on the fragmentation chemistry of gas-phase peptide ions as well as the level of information that can be extracted regarding the specificity of metal ion binding.

\section{Acknowledgments}

The authors acknowledge support for this research by the Robert A. Welch Foundation (A-1176), the U. S. Department of Energy, Division of Chemical Sciences, BES (DE-FGO2-04ER15520), and the National Science Foundation (DBI-0821700).

\section{Appendix A Supplementary Material}

Supplementary material associated with this article may be found in the online version at doi:10.1016/ j.jasms.2009.12.020.

\section{References}

1. Lippard, S. J.; Berg, J. M. Principles of Bioinorganic Chemistry; University Science Books: Mill Valley, CA, 1994; pp 3-35.

2. Villafranca, J. J.; Desai, P. R. Copper Proteins: A Review of the Different Classes of Copper Proteins and an In-Depth Investigation of the Active Copper Sites in Dopamine $\beta$-Hydroxylase. Biol. Oxidat. Syst. 1990, 1, 297-327.

3. Sancenon, V.; Puig, S.; Mira, H.; Thiele, D. J.; Penarrubia, L. Identification of a Copper Transporter Family in Arabidopsis thaliana Plant. Mol. Biol. 2003, 51, 577-587.

4. Marschner, H. Mineral Nutrition of Higher Plants; Academic Press: New York, 1995; pp 335-347.

5. Raffa, D. F.; Gomez-Balderas, R.; Brunelle, P.; Rickard, G. A.; Rauk, A. $\mathrm{Ab}$ Initio Model Studies of Copper Binding to Peptides Containing a His-His Sequence: Relevance to the $\beta$-Amyloid Peptide of Alzheimer's Disease. J. Biol. Inorg. Chem. 2005, 10, 887-902.

6. Valentine, J. S.; Gralla, E. B. Advances in Protein Chemistry: CopperContaining Proteins, Vol. LX; Academic Press: San Diego, CA, 2002.

7. Martell, A. E. Metal Complexes in Aqueous Solutions; Plenum: New York, 1996; pp 199-212.

8. Russell, D. H. Gas Phase Inorganic Chemistry; Plenum: New York, 1989; pp 1-40.

9. Freiser, B. S. Organometallic Ion Chemistry, Vol. XV; Kluwer Academic, Boston, 1996.

10. Turecek, F. Copper-Biomolecule Complexes in the Gas Phase. The Ternary Way. Mass Spectrom. Rev. 2007, 26, 563-582.
11. Gatlin, C. L.; Turecek, F.; Vaisar, T. Copper(II) Amino-Acid Complexes in the Gas Phase. I. Am. Chem. Soc. 1995, 117, 3637-3638.

12. Wen, D.; Yalcin, T.; Harrison, A. G. Fragmentation Reactions of $\mathrm{Cu}^{+}$ Cationated $\alpha$-Amino-Acids. Rapid Commun. Mass Spectrom. 1995, 9, 1155-1157.

13. Shields, S. J.: Bluhm, B. K.; Russell, D. H. Fragmentation Chemistry of $[\mathrm{M}+\mathrm{Cu}]^{+}$Peptide Ions Containing an N-Terminal Arginine. J. Am. Soc. Mass Spectrom. 2000, 11, 626-638.

14. Lausarot, P. M.; Operti, L.; Vaglio, G. A. Reactions of $\mathrm{Cu}(\mathrm{Ii})$ with $\alpha$-Amino-Acids Investigated by Fast-Atom-Bombardment (Fab) Mass Spectrometry. Org. Mass Spectrom. 1991, 26, 51-52.

15. Nelson, R. W.; Hutchens, T. W. Mass-Spectrometric Analysis of a Transition-Metal-Binding Peptide Using Matrix-Assisted Laser-Desorption Time-of-Flight Mass-Spectrometry-a Demonstration of Probe Tip Chemistry. Rapid Commun. Mass Spectrom. 1992, 6, 4-8

16. Bouchonnet, S.; Hoppilliard, Y.; Ohanessian, G. Formation and Fragmentations of Organometallic Complexes Involving Aliphatic $\alpha$-Amino-Acids and Transition-Metal Cations-a Plasma Desorption Mass Spectrometry Study. J. Mass Spectrom. 1995, 30, 172-179.

17. Bluhm, B. K.; Shields, S. J.; Bayse, C. A.; Hall, M. B.; Russell, D. H. Determination of Copper Binding Sites in Peptides Containing Basic Residues: A Combined Experimental and Theoretical Study. Int. J. Mass Spectrom. 2001, 204, 31-46.

18. Prudent, M.; Girault, H. H. On-Line Electrogeneration of CopperPeptide Complexes in Microspray Mass Spectrometry. J. Am. Soc. Mass Spectrom. 2008, 19, 560-568.

19. Lim, J.; Vachet, R. W. Development of a Methodology Based on Metal-Catalyzed Oxidation Reactions and Mass Spectrometry to Determine the Metal Binding Sites in Copper Metalloproteins. Anal. Chem. 2003, 75, 1164-1172.

20. Bridgewater, J. D.; Lim, J.; Vachet, R. W. Using Metal-Catalyzed Oxidation Reactions and Mass Spectrometry to Identify Amino Acid Residues within $10 \AA$ of the Metal in Cu-Binding Proteins. J. Am. Soc. Mass Spectrom. 2006, 17, 1552-1559.

21. Bridgewater, J. D.; Vachet, R. W. Using Microwave-Assisted MetalCatalyzed Oxidation Reactions and Mass Spectrometry to Increase the Rate at which the Copper-Binding Sites of a Protein are Determined. Anal. Chem. 2005, 77, 4649-4653.

22. Wu, Z.; Fernandez-Lima, F. A. Perez, L. M. Russell, D. H. A New Copper Containing MALDI Matrix that Yields High Abundances of $[\text { Peptide }+\mathrm{Cu}]^{+}$Ions. J. Am. Soc. Mass Spectrom. 2009, 20, 1263-1271.

23. Abajian, C.; Yatsunyk, L. A.; Ramirez, B. E.; Rosenzweig, A. C. Yeast Cox17 Solution Structure and Copper(I) Binding. J. Biol. Chem. 2004, 279, $53584-53592$

24. Arnesano, F.; Balatri, E.; Banci, L.; Bertini, I.; Winge, D. R. Folding Studies of Cox17 Reveal an Important Interplay of Cysteine Oxidation and Copper Binding. Structure 2005, 13, 713-722.

25. Fujiwara, N.: Nakano, M.; Kato, S.; Yoshihara, D.: Ookawara, T.; Eguchi, H.; Taniguchi, N.; Suzuki, K. Oxidative Modification to Cysteine Sulfonic Acid of Cys(111) in Human Copper-Zinc Superoxide Dismutase. J. Biol. Chem. 2007, 282, 35933-35944.

26. De Beus, M. D.; Chung, J. Y.; Colon, W. Modification of Cysteine 111 in $\mathrm{Cu} / \mathrm{Zn}$ Superoxide Dismutase Results in Altered Spectroscopic and Biophysical Properties. Protein Sci. 2004, 13, 1347-1355.

27. Hay, R. W. Bioinorganic Chemistry; Ellis Honvood Ltd.: Chichester, 1984; pp 102-150.

28. Kaim, W.: Schwederski, B. Bioinorganic Chemistry: Inorganic Elements in the Chemistry of Life; John Wiley and Sons: Chichester, 1994; pp 12-48.

29. Zheng, H.; Chruszcz, M.; Lasota, P.; Lebioda, L.; Minor, W. Data Mining of Metal Ion Environments Present in Protein Structures. J. Inorg. Biochem. 2008, 102, 1765-1776.

30. Hodgson, E. K.; Fridovich, I. Interaction of Bovine Erythrocyte SuperoxideDismutase with Hydrogen-Peroxide-Chemiluminescence and Peroxidation. Biochemistry 1975, 14, 5299-5303.

31. Chaparro, A. L.; Vachet, R. W. Tandem Mass Spectrometry of $\mathrm{Cu}(\mathrm{II})$ Complexes: The Effects of Ligand Donor Group on Dissociation. J. Mass Spectrom. 2003, 38, 333-342.

32. Combariza, M. Y.; Fahey, A. M.; Milshteyn, A.; Vachet, R. W. Gas-Phase Ion-Molecule Reactions of Divalent Metal Complex Ions: Toward Coordination Structure Analysis by Mass Spectrometry and Some Intrinsic Coordination Chemistry Along the Way. Int. J. Mass Spectrom. 2005, 244 $109-124$.

33. Tian, Z. X.; Pawlow, A.; Poutsma, J. C.; Kass, S. R. Are Carboxyl Groups the Most Acidic Sites in Amino Acids? Gas-Phase Acidity, H/D Exchange Experiments, and Computations on Cysteine and Its Conjugate Base. J. Am. Chem. Soc. 2007, 129, 5403-5407.

34. Sechi, S.; Chait, B. T. Modification of Cysteine Residues by Alkylation A Tool in Peptide Mapping and Protein Identification. Anal. Chem. 1998, 70, 5150-5158.

35. Crankshaw, M. W.; Grant, G. A. Modification of Cysteine, Current Protocols in Protein Science, Vol. 15.1; Wiley Interscience: Hoboken, NJ, 1996.

36. Lee, C. T.; Yang, W. T.; Parr, R. G. Development of the Colle-Salvetti Correlation-Energy Formula into a Functional of the Electron-Density. Phys. Rev. B 1988, 37, 785-789.

37. Becke, A. D. Density-Functional Thermochemistry. 3. The Role of Exact Exchange. J. Chem. Phys. 1993, 98, 5648-5652.

38. Stephens, P. J.; Devlin, F. J.; Chabalowski, C. F.; Frisch, M. J. Ab Initio Calculation of Vibrational Absorption and Circular-Dichroism Spectra 
Using Density-Functional Force-Fields. J. Phys. Chem. 1994, 98, 1162311627.

39. Hay, P. J.; Wadt, W. R. Ab Initio Effective Core Potentials for Molecular Calculations-Potentials for $\mathrm{K}$ to $\mathrm{Au}$ Including the Outermost Core Orbitals. J. Chem. Phys. 1985, 82, 299-310.

40. Jaguar 6.0 manual; Schroedinger Inc: Portland, OR, 2004
41. Men, L. J.; Wang, Y. S. Fragmentation of the Deprotonated Ions of Peptides Containing Cysteine, Cysteine Sulfinic Acid, Cysteine Sulfonic Acid, Aspartic Acid, and Glutamic Acid. Rapid Commun. Mass Spectrom. 2006, 20, 777-784.

42. Cerda, B. A.; Wesdemiotis, C. The Relative Copper(I) Ion Affinities of Amino-Acids in the Gas Phase. J. Am. Chem. Soc. 1995, 117, 9734-9739. 